\title{
Large estragole fluxes from oil palms in Borneo
}

\author{
P. K. Misztal ${ }^{1,2}$, S. M. Owen ${ }^{1}$, A. B. Guenther ${ }^{4}$, R. Rasmussen ${ }^{6}$, C. Geron ${ }^{5}$, P. Harley ${ }^{4}$, G. J. Phillips ${ }^{1}$, A. Ryan ${ }^{3}$, \\ D. P. Edwards ${ }^{7}$, C. N. Hewitt ${ }^{3}$, E. Nemitz ${ }^{1}$, J. Siong ${ }^{8,1}$, M. R. Heal ${ }^{2}$, and J. N. Cape ${ }^{1}$ \\ ${ }^{1}$ Centre for Ecology \& Hydrology, Penicuik, EH26 0QB, UK \\ ${ }^{2}$ School of Chemistry, University of Edinburgh, Edinburgh, EH9 3JJ, UK \\ ${ }^{3}$ Lancaster Environment Centre, Lancaster University, Lancaster, LA1 4YQ, UK \\ ${ }^{4}$ Atmospheric Chemistry Division, National Center for Atmospheric Research, 1850 Table Mesa Drive, Boulder, \\ Colorado, 80305, USA \\ ${ }^{5}$ US Environmental Protection Agency, National Risk Management Research Laboratory, Mail Drop E305-02, 109 TW \\ Alexander Dr., Research Triangle Park, NC 27711, USA \\ ${ }^{6}$ Department of Environmental Science and Engineering, Oregon Graduate Institute, P.O. Box 91000, Portland, \\ OR 97291, USA \\ ${ }^{7}$ Institute of Integrative and Comparative Biology, University of Leeds, Leeds, LS2 9JT, UK \\ ${ }^{8}$ School of Science and Technology, Universiti Malaysia Sabah, 88999, Malaysia
}

Received: 15 December 2009 - Published in Atmos. Chem. Phys. Discuss.: 20 January 2010

Revised: 28 April 2010 - Accepted: 29 April 2010 - Published: 7 May 2010

\begin{abstract}
During two field campaigns (OP3 and ACES), which ran in Borneo in 2008, we measured large emissions of estragole (methyl chavicol; IUPAC systematic name 1allyl-4-methoxybenzene; CAS number 140-67-0) in ambient air above oil palm canopies $\left(0.81 \mathrm{mg} \mathrm{m}^{-2} \mathrm{~h}^{-1}\right.$ and $3.2 \mathrm{ppbv}$ for mean midday fluxes and mixing ratios respectively) and subsequently from flower enclosures. However, we did not detect this compound at a nearby rainforest. Estragole is a known attractant of the African oil palm weevil (Elaeidobius kamerunicus), which pollinates oil palms (Elaeis guineensis). There has been recent interest in the biogenic emissions of estragole but it is normally not included in atmospheric models of biogenic emissions and atmospheric chemistry despite its relatively high potential for secondary organic aerosol formation from photooxidation and high reactivity with $\mathrm{OH}$ radical. We report the first direct canopy-scale measurements of estragole fluxes from tropical oil palms by the virtual disjunct eddy covariance technique and compare them with previously reported data for estragole emissions from Ponderosa pine. Flowers, rather than leaves, appear to be the main source of estragole from oil palms; we derive a
\end{abstract}

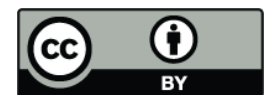

Correspondence to: P. K. Misztal (pawel.m@ed.ac.uk) global estimate of estragole emissions from oil palm plantations of $\sim 0.5 \mathrm{Tg} \mathrm{y}^{-1}$. The observed ecosystem mean fluxes $\left(0.44 \mathrm{mg} \mathrm{m}^{-2} \mathrm{~h}^{-1}\right)$ and mean ambient volume mixing ratios $(3.0 \mathrm{ppbv})$ of estragole are the highest reported so far. The value for midday mixing ratios is not much different from the total average as, unlike other VOCs (e.g. isoprene), the main peak occurred in the evening rather than in the middle of the day. Despite this, we show that the estragole flux can be parameterised using a modified G06 algorithm for emission. However, the model underestimates the afternoon peak even though a similar approach works well for isoprene. Our measurements suggest that this biogenic compound may have an impact on regional atmospheric chemistry that previously has not been accounted for in models and could become more important in the future due to expansion of the areas of oil palm plantation.

\section{Introduction}

Estragole or 1-allyl-4-methoxybenzene (AMOB) is an oxygenated volatile organic compound (OVOC) with molecular weight of 148 and a boiling point of $216^{\circ} \mathrm{C}$ at atmospheric pressure, and therefore should be regarded as a semi-volatile organic compound. Although it is a C-10

Published by Copernicus Publications on behalf of the European Geosciences Union. 
compound $\left(\mathrm{C}_{10} \mathrm{H}_{12} \mathrm{O}\right)$ it is not classified as terpenoid because it is produced by the phenylpropanoid pathway rather than a terpenoid pathway. It has many synonyms, of which the most commonly used after estragole are methyl chavicol, p-allylanisole, isoanethole, chavicyl methyl ether or 1-methoxy-4-prop-2-enylbenzene. Estragole is the original name attributed to the compound and it is used throughout this article. It derives from "estragon", the French and German word for tarragon (Artemesia dracunculus), a herb to which it gives its anis-like odour.

Even though estragole was reported to be a major component of ponderosa pine emissions almost 30 years ago (Altshuller, 1983), the growing interest in this compound in the atmospheric science community has been relatively recent. The interest follows analytical improvements over the last decade which have extended biogenic emission studies to a wider variety of compounds, including estragole. Bouvier-Brown et al. (2009a) recently reported measurements of estragole emissions and ambient concentrations from ponderosa pine trees and highlighted the importance this compound might have for atmospheric chemistry. Lee et al. (2006b) found that the secondary organic aerosol (SOA) yield from full photochemical oxidation of this compound was the highest of all oxygenated terpenes (40\%) and also that it was significantly higher than the SOA yield from its ozonolysis (6\%) (Lee et al., 2006a). Emissions of estragole from oil palms have not yet been quantified even though, as shown later, they exceed many times those reported from other species, and thus their contribution to regional photochemistry is likely to be considerable. Estragole, like many other BVOCs, is suspected to be harmful to human health at high concentrations (EPA, 2002).

The area of oil palm (Arecaceae Elaeis) plantations is rapidly expanding in South East Asia, in order to meet the global demand for palm oil. Globally the land area of oil palm plantations is estimated at 13.9 million hectares, where the majority $(60 \%)$ is concentrated in Malaysia (3.8 Mha) and Indonesia (4.6 Mha) (FAO, 2009). The oil palm cultivated there is usually a high yielding cross between dura and pisifera forms of Elaeis guineensis Jacq., which is native to tropical Africa, or hybrids of E. guineensis with E. oleifera, which is native to Latin America. Plantation area has increased in Malaysia from 55000 hectares in 1960, to half a million in 1975, and a million hectares were under cultivation in 1980 (Hartley, 1988). Nowadays the area is nearly 4 million ha.

It was originally thought that the oil palm is mainly wind pollinated, until Syed (1979) showed experimentally that the oil palm is mainly insect pollinated. Estragole is the known attractant for the weevil (Elaeidobius kamerunicus Faust) which is the specific pollinator of Elaeis guineensis flowers. E. guineensis is monoecious containing both female and male flowers on one tree which open at different times and which are pollinated all year round (Henderson, 1986; Syed, 1979; Tandon et al., 2001). This weevil responds specifically to estragole and not its derivatives, as was experimentally shown by Hussein et al. (1989). It is not native to Borneo but was introduced from Cameroon in 1981 for the purpose of improving pollination and increasing crop yields (Hartley, 1988). The specificity of the pollinator and lack of predators led to a great success for the palm oil industry, saving tens of million pounds on hand pollination (Hussein et al., 1991). Estragole emissions are therefore of great importance to the oil palm industry.

The lifetime of estragole in the atmosphere has been estimated for temperate latitudes by Bouvier-Brown et al. (2009a) as $55 \mathrm{~min}$ and $18 \mathrm{~h}$ for reaction with $\mathrm{OH}$ and $\mathrm{O}_{3}$, respectively, suggesting that this compound can have an impact on regional photochemistry. Estragole oxidation is not included in the Master Chemical Mechanism $(\mathrm{MCM})^{1}$, nor are any other aromatic species with methoxy or 2-propenyl substituents. The reactivity of estragole to $\mathrm{OH}$ might be expected to be similar to that of methoxybenzene, or the methoxy-substituted aromatic ring $\left(\sim 3 \times 10^{-11} \mathrm{~cm}^{3}\right.$ molecule $\left.{ }^{-1} \mathrm{~s}^{-1}\right)$, with the side chain reacting similarly to a terminal alkene (M. E. Jenkin, personal communication, 2009). Recently, BouvierBrown et al. (2009a) reported two consistent estimates for $k_{\mathrm{OH}}$ of $5.7 \times 10^{-11} \mathrm{~cm}^{3}$ molecule $\mathrm{e}^{-1} \mathrm{~s}^{-1}$ from ozonolysis studies performed by Lee et al. (2006a, b) and $5.4 \times 10^{-11} \mathrm{~cm}^{3}$ molecule ${ }^{-1} \mathrm{~s}^{-1}$ derived using the Environmental Protection Agency's Estimation Program Interface Suite (EPA, 2000). These are similar to the $k_{\mathrm{OH}}$ value for 2-methyl-3-buten-2-ol (MBO). The same authors also estimated rate coefficients for the reaction of estragole with ozone $\left(k_{\mathrm{O}_{3}}\right)$ of $1.4 \times 10^{-17} \mathrm{~cm}^{3}$ molecule ${ }^{-1} \mathrm{~s}^{-1}$ and $1.2 \times 10^{-17} \mathrm{~cm}^{3}$ molecule $\mathrm{e}^{-1} \mathrm{~s}^{-1}$, respectively, using the same experimental and modelling approaches. It would be anticipated that the initial stages of estragole degradation are efficient at generating ozone, since 1-alkenes typically have photochemical ozone creation potentials (POCP) of around 100. On the other hand, if degradation leads to compounds of structures similar to benzaldehyde or nitrophenols, then the impact on ozone formation will be near zero or negative since these compounds lead to near-irreversible sequestration of $\mathrm{NO}_{\mathrm{x}}$ and organic material into species which deposit efficiently or are incorporated into aerosol. But in that case, estragole would be expected to act as an efficient SOA precursor. In both instances estragole oxidation will likely have an impact on regional photochemistry.

In May and June 2008 measurements of VOC fluxes by virtual disjunct eddy covariance (continuous flow disjunct) were made using proton transfer reaction mass spectrometry (PTR-MS), and were supplemented by GC-MS study (leaf level and ambient) at an oil palm plantation in Sabah, Borneo (Misztal et al., 2010). Estragole was the second most abundant BVOC (after isoprene) at the plantation and the

\footnotetext{
${ }^{1}$ http://mom.leeds.ac.uk/MCM/
} 
observed concentration and fluxes are the highest reported so far from vegetation.

\section{Methods}

\subsection{Site and setup}

The experiment site was a flat 33 ha commercial oil palm plantation located at $5^{\circ} 14^{\prime} 52.67(\mathrm{~N})$ latitude and $118^{\circ} 27^{\prime} 14.96$ (E) longitude within a much larger oil palm area belonging to the Sabahmas Oil Palm Plantation owned by Wilmar International Ltd. (Fig. 1). This location is $28 \mathrm{~km}$ NE of Lahad Datu in the Malaysian province of Sabah in NE Borneo. The palms were 12 year old $E$. guineensis $\times E$. oleifera hybrids of the progeny "Gutherie", with an average height of $12 \mathrm{~m}$ and a single-sided leaf area index (LAI) of about 6, planted at a commercial density of 124 trees per ha. The suite of atmospheric measurements at this site and a rainforest site during the OP3 and ACES measurement campaigns is summarised in the introductory paper of this issue (Hewitt et al., 2010).

\subsection{Proton Transfer Reaction Mass Spectrometer (PTR-MS)}

A Proton Transfer Reaction Mass Spectrometer (PTR-MS) was employed to monitor the VOC concentrations and eddy fluxes of various compounds including estragole. The PTRMS instrument was a high sensitivity model (Ionicon Innsbruck, Austria, s/n: 04-03) incorporating an additional turbopump for the detection chamber and Teflon instead of Viton rings in the drift tube. In addition in our instrument the Pfeiffer turbopumps have been replaced by their Varian analogues. Operational details have been described elsewhere (e.g. de Gouw et al., 2003; Lindinger et al., 1998), and very recently the PTR-MS technique has been reviewed by Blake et al. (2009), hence only a brief description is presented here. The VOCs under study, whose proton affinities exceed that of water, are soft-ionised in a drift tube by collision with hydronium ions, formed in the hollow cathode of the ion source. The products of the proton transfer reactions are either protonated compounds or their protonated fragments or clusters. The magnitude of fragmentation/clustering can be optimised by adjusting the electric field $(E)$ and the buffer gas number density $(N)$ in the drift tube, so that the $E / N$ ratio is most commonly in the range of $120-140 \mathrm{Td}\left(1 \mathrm{Td}=10^{-17} \mathrm{~V} \mathrm{~cm}^{2}\right)$. The relative abundance of the product cations, separated by the quadrupole mass filter, can be derived from the number of pulses counted by the Secondary Electron Multiplier (SEM) during a given dwell time. During the PTR-MS measurements at the plantation the $E / N$ ratio was kept constant at $140 \mathrm{Td}$ by adjusting drift tube parameters of pressure to $160 \mathrm{~Pa}$, temperature to $45^{\circ} \mathrm{C}$ and the drift voltage to $485 \mathrm{~V}$. The sampling inlet and the $20 \mathrm{~Hz}$ sonic anemometer (Solent R3, Gill Instruments) were

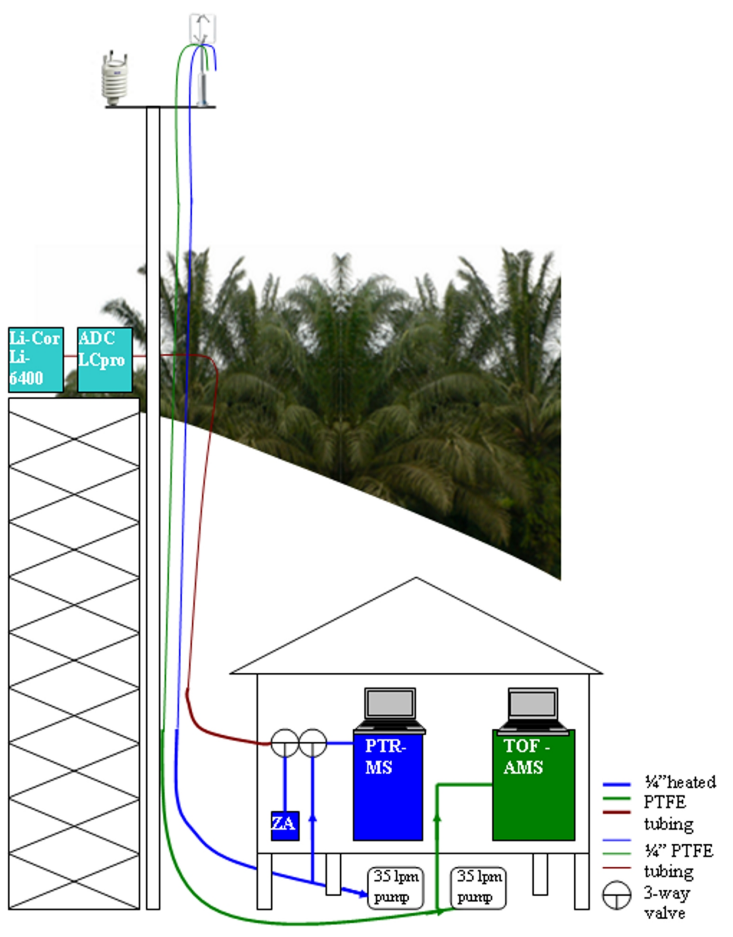

Fig. 1. Schematic of the sampling setup at the Sabahmas Oil Palm plantation, Borneo. Measurements of estragole (and other VOCs) were made at canopy and leaf level using proton-transfer-reaction mass spectrometry (PTR-MS) and leaf cuvettes (Li-COR Li-6400 and ADC LCpro). ZA refers to the zero-air (pure air) generator, and TOF-AMS refers to a time-of-flight aerosol mass spectrometer deployed at the site. In addition, a portable gas chromatograph with a mass spectrometer (Hapsite Smart, Inficon, East Syracuse NY) was used (not presented here) for ambient air and enclosure in-situ analysis.

placed above the canopy at about $15 \mathrm{~m}$. A $20 \mathrm{~m}$ PTFE sampling line (1/4" OD, 3/16" ID) was used to draw a flow rate of $35 \mathrm{~L} \mathrm{~min}^{-1}$ past the instrument, which sub-sampled at a flow rate of $400 \mathrm{~mL} \mathrm{~min}^{-1}$. The instrument and PTFE tubing were protected against water condensation by heating above the ambient temperature (approx. $50^{\circ} \mathrm{C}$ ) using a heating tape (Omega, UK type SRF3-2C self regulating heat cable). In order to get absolute volume mixing ratios, either calibration with an external standard is required, or less precise calculation can be made based on the calibrated transmission of the instrument and the proton transfer reaction rate of estragole. As no estragole calibration standard was available for PTR-MS at the site, the instrument was calibrated against several other VOCs (i.e. methanol, acetonitrile, acetone, acetaldehyde, isoprene, a monoterpene: d-limonene) and then the relative transmission curve was obtained to yield an empirical calibration coefficient for estragole (method described by Taipale et al., 2008). We checked the validity of this approach by comparison with a vapourised estragole standard (98\%; Sigma Aldrich) and the results were well within 
$30 \%$ of the values obtained from the relative transmission approach used in the field.

The biggest advantage of PTR-MS is the high frequency of data acquisition, which makes it suitable for use in micrometeorological flux measurement techniques such as eddy covariance (EC). Here, data were processed according to the virtual disjunct eddy covariance concept (Karl et al., 2002; Rinne et al., 2001), where for each $\mathrm{m} / \mathrm{z}$ of interest the PTRMS makes a measurement which is sufficiently fast (as determined by the dwell and instrument response time), but discontinuous (while the PTR-MS scans the other $\mathrm{m} / \mathrm{z}$ of interest), thus providing fewer data points than continuous EC. For the flux mode the instrument was running in the multiple ion detection (MID) for 25 min every half hour cycling through $13 \mathrm{~m} / z$ channels including estragole and remaining 10 VOC-related protonated masses analysed at $0.5 \mathrm{~s}$ dwell time each, whereas a shorter $0.2 \mathrm{~s}$ dwell time was used for the hydronium $\left(\mathrm{H}_{3}{ }^{18} \mathrm{O}^{+}\right)$ions measured at $\mathrm{m} / z, 21$ and water clusters $\left(\mathrm{H}_{2} \mathrm{O}\right) \mathrm{H}_{3} \mathrm{O}^{+}$measured at $\mathrm{m} / \mathrm{z} 37$. This corresponded to a cycle length of $7 \mathrm{~s}$ with 210 PTR-MS and 30000 wind rows in $25 \mathrm{~min}$. The effective time lag associated with the residence time in the tubing was calculated from the crosscorrelation between vertical wind speed and the VOC mixing ratio as a function of lag time (Davison et al., 2009; Langford et al., 2009; Rinne et al., 2007; Spirig et al., 2005). If no detectable peak was present in the covariance function, or if it was smaller than the detection limit derived by multiplying the standard deviation of the noise over $180 \mathrm{~s}$ by 1.5 , or if the lag time was not stable during an averaging period $(25 \mathrm{~min})$, then the flux data point was discarded. In addition, the data were filtered for stationarity using the criterion of Foken and Wichura (1996), for low friction velocity $\left(u_{*}<0.15 \mathrm{~m} \mathrm{~s}^{-1}\right)$, and for rain events. More than one fifth of the data for estragole flux passed all these validation criteria. In order to assess the likely impact on the representativeness of the time series which followed the rejections, the volume mixing ratio (VMR) data corresponding to rejected flux periods was compared with the full VMR time series. Although their diurnal average pattern became noisier as a result of those rejections (as later shown in Fig. 5), the total average VMR did not change by more than $0.1 \%$.

Estragole is detected at $\mathrm{m} / z, 149$ in PTR-MS as the protonated molecular ion. It was measured for the first time with PTR-MS in ambient air by Holzinger et al. (2005). This compound is relatively resistant to fragmentation at typical working conditions, with only small fragmentation to $\mathrm{m} / \mathrm{z}$ 121, and thus PTR-MS can be used reliably for monitoring its concentrations and fluxes. There are only a few known minor contributions to $\mathrm{m} / \mathrm{z}, 149$ from other compounds that have been reported so far, of which the most significant are from sesquiterpenes (Bouvier-Brown et al., 2007; BouvierBrown et al., 2009b; Helmig et al., 2006; Kim et al., 2009). When the volume mixing ratio of sesquiterpenes relative to estragole is very low, one can assume these contributions to be insignificant. In addition, a GC-MS was used to check the ambient air for any interference with the $m / z, 149$ signal. Fluxes of other compounds measured with the PTR-MS at the oil palm plantation included isoprene, total monoterpenes and methanol. These results are presented in a separate paper (Misztal et al., 2010).

\subsection{Gas chromatography (GC-MS)}

\subsubsection{Leaf cuvette sampling method}

Two types of leaf cuvette were used for sampling VOC emissions, an ADC LCpro (ADC Bioscientific Ltd. UK), and a LiCor Li-6400 (Li-Cor, Inc., Lincoln, Nebraska, USA). Both types of cuvette are portable photosynthesis systems, measuring water vapour $\left(\mathrm{H}_{2} \mathrm{O}\right)$ and carbon dioxide $\left(\mathrm{CO}_{2}\right)$ exchange across the leaf surfaces with infrared gas analyzers (IRGAs) and allowing control of photosynthetic photon flux density (PPFD), leaf and air temperature, humidity, $\mathrm{CO}_{2}$ concentration, and airflow rate. They were adapted for sampling VOC emissions by introducing a sampling port in the gas line exiting the cuvette.

Before each measurement campaign, the leaf cuvettes had been serviced and checked, and were in optimal working order. A charcoal filter was fitted to the inflow of the leaf cuvettes to remove ambient BVOCs and ozone. This had the effect of elevating the ambient $\mathrm{CO}_{2}$ concentrations by about $50 \mathrm{ppm}$ on average in the LCpro, but this was fairly consistent for all emission samples. While this is a little higher than the average ambient $\left[\mathrm{CO}_{2}\right]$, there are several reports of high $\left[\mathrm{CO}_{2}\right]$ between 1 and $5 \mathrm{~m}$ from a tropical forest floor during the morning and later in the afternoon (e.g. Buchmann et al., 1997; Culf et al., 1999). Rosenstiel et al. (2003) found that increasing $\mathrm{CO}_{2}$ concentrations reduces canopy isoprene emission and decouples isoprene emissions from photosynthesis; however, they worked with concentrations of 800 and $1200 \mathrm{ppm}$, which is far higher than the concentrations the sampled leaves experienced in the investigation reported here $(400 \mathrm{ppm})$. Using a charcoal trap to clean inflowing air would result in upper-limit emission measurements because purified air would lead to a higher concentration gradient of emitted compound than between leaf air space and ambient air.

Inter-comparison experiments performed during previous studies showed that BVOC emissions measured using the ADC LCpro cuvette system were similar to those measured using the Li-COR system (Geron et al., 2006). The leaf cuvettes were installed on a leaf and left to equilibrate for $45 \mathrm{~min}$ before VOC samples were taken. Flow rate through the ADC LCpro was $300 \mathrm{~mL} \mathrm{~min}^{-1}$, and $500 \mathrm{~mL} \mathrm{~min}^{-1}$ through the Li-COR. Sampled leaf areas in the ADC LCpro and Li-COR were $6.25 \mathrm{~cm}^{2}$ and $6 \mathrm{~cm}^{2}$, respectively. Photosynthetically active radiation (PAR) in the leaf cuvettes was set at an optimum (i.e. $500 \mu \mathrm{mol} \mathrm{m} \mathrm{m}^{-2} \mathrm{~s}^{-1}$ for plants under the canopy; $1000 \mu \mathrm{mol} \mathrm{m}{ }^{-2} \mathrm{~s}^{-1}$ for plants that are exposed to sunlight). Carbon dioxide and humidity were both set to 
ambient conditions to simulate the plant's actual field condition. Leaf temperature was set at $30^{\circ} \mathrm{C}$ or slightly higher to minimise condensation in the cuvettes.

Samples were analyzed by three independent methods including an in-situ portable GC-MS, collection in stainless steel canisters transported to laboratory for analysis, and collection on solid adsorbent cartridges transported to laboratory for analysis. Sample cartridges were filled with 100 mg Carbotrap and $200 \mathrm{mg}$ Tenax and conditioned for $15 \mathrm{~min}$ at $300^{\circ} \mathrm{C}$ in a flow of helium. Cartridges prepared in this way have been used in our laboratory for many years, and are always very consistent in their adsorbent properties. A cartridge was fitted to the cuvette outlet port, and air from the cuvette drawn through it at $100-120 \mathrm{~mL} \mathrm{~min}^{-1}$ using an SFK mass flow controlled pocket sampling pump. This range of flow rates ensured that only cuvette air was sampled, and was not contaminated with outside air. Samples were taken for 10-20 min, and the cartridges were stored in a refrigerator until returned to $\mathrm{CEH}$, Edinburgh, UK, for analysis using gas chromatography with mass selective detection (GC-MS). In a previous study using the same sampling and analytical system, changes in sample compound content were assessed during storage and transport. Overall, there was between $0.1 \%$ and $10.4 \%$ more of each compound in the transported standard tubes compared with freshly injected standards, but differences were not significant, due to variability in different batches of diluted standards (Wang et al., 2007). In addition, a sample was taken from an empty leaf cuvette each day to give a blank value which was subtracted from emission samples.

\subsubsection{GC-MS analysis}

Leaf samples were analysed using a GC-MS system. A thermal desorption autosampler (Perkin-Elmer ATD 400) was connected via a heated $\left(200^{\circ} \mathrm{C}\right)$ transfer line to a HewlettPackard 5890 GC with a 5970 mass-selective detector.

Compounds were desorbed at $280^{\circ} \mathrm{C}$ for $5 \mathrm{~min}$ at $25 \mathrm{~mL} \mathrm{~min}^{-1}$ onto a Tenax-TA cold trap maintained at $-30^{\circ} \mathrm{C}$. Secondary desorption was at $300^{\circ} \mathrm{C}$ for $6 \mathrm{~min}$ onto the GC column. Separation of the compounds was achieved using an Ultra-2 column, Agilent Technologies $(50 \mathrm{~m} \times 0.2 \mathrm{~mm} \mathrm{ID} \times 0.11 \mu \mathrm{m}$ film, $5 \%$ phenylmethyl silica). The initial oven temperature of $35^{\circ} \mathrm{C}$ was maintained for 2 min, then increased at $4{ }^{\circ} \mathrm{C} \mathrm{min}^{-1}$ to $160^{\circ} \mathrm{C}$ followed by an increase of $45^{\circ} \mathrm{C} \mathrm{min}^{-1}$ to $300^{\circ} \mathrm{C}$ which was maintained for $10 \mathrm{~min}$. The carrier gas was helium at $\sim 1 \mathrm{~mL} \mathrm{~min}^{-1}$, the injector temperature was $250^{\circ} \mathrm{C}$. For this system, the limit of detection for isoprene and monoterpenes was approximately $0.25 \mathrm{ng}$ on column, whereas for sesquiterpenes it was $2 \mathrm{ng}$ on column. This corresponded to $100 \mathrm{pptv}$ of isoprene, $50 \mathrm{pptv}$ of monoterpenes, and to $400 \mathrm{pptv}$ of sesquiterpenes in a $1 \mathrm{~L}$ sample. The level of analytical precision was around $6.5 \%$ for isoprene, $5 \%$ for monoterpenes and $10 \%$ for sesquiterpenes.
Monoterpene and estragole quantification was by comparison with commercially available liquid standards (Aldrich, Fluka and Sigma) appropriately diluted in methanol solution before injecting on column, and isoprene quantification by comparison with a $1 \mathrm{ppmV}$ in $\mathrm{N}_{2}$ certified gas standard (Air Products UK). Chemstation for Microsoft Windows was used to handle chromatographic data. Identification was achieved by comparison of retention times and mass spectra of authentic standards. Samples were analysed in "scan" mode, but subsequent quantification was achieved by standard calibration and integration of selected ion spectra for isoprene $(\mathrm{m} / \mathrm{z}$ 67) and monoterpenes $(\mathrm{m} / \mathrm{z}$ 93). Ions for identification of estragole were at $\mathrm{m} / \mathrm{z}, 148,147,77,121$, and 117 and the estragole peak appeared at retention time $28.15 \mathrm{~min}$, confirmed by comparison with library spectra.

Ambient air and enclosure samples were also analyzed insitu with a portable gas chromatograph with a mass spectrometer (Hapsite Smart, Inficon, East Syracuse NY) using a $30 \mathrm{~m} \times 0.32 \mathrm{~mm} \mathrm{ID} \times 1 \mu \mathrm{m}$ film DB- 1 column, temperature programmed with an initial $2 \mathrm{~min}$ hold at $40^{\circ} \mathrm{C}$ followed by a $15^{\circ} \mathrm{C} \mathrm{min}-1$ ramp to $80^{\circ} \mathrm{C}$ followed by a $3^{\circ} \mathrm{C} \mathrm{min}^{-1}$ ramp to $110^{\circ} \mathrm{C}$ followed by a $9^{\circ} \mathrm{C} \mathrm{min}^{-1}$ ramp to $200^{\circ} \mathrm{C}$ with a final 6 min hold. VOCs were quantified with respect to an internal standard referenced to NIST traceable standards.

\subsubsection{Flower enclosures}

Male and female inflorescences were enclosed using wide transparent Teflon bags $(80 \mathrm{~L})$, which were open at both ends. The bags were secured gently around the base of the inflorescence with a cable tie. The other end of the Teflon bag was also closed with a cable tie around the whole inflorescence, leaving enough of a gap to insert a stainless steel sample tube ( $6 \mathrm{~mm}$ OD) filled with Tenax and Carbotrap (as above). The system was static, and after installation, was left for an hour to allow any compounds emitted from the flowers to accumulate inside the Teflon enclosure. A sample tube was then inserted into the small gap left at the closed end. The sample tube was attached to a pump and sampled at a rate of $150 \mathrm{~mL} \mathrm{~min}^{-1}$ for $15 \mathrm{~min}$, giving a total sample volume of $2.25 \mathrm{~L}$. During sampling it was inevitable that air flowed into the Teflon enclosure from outside via the gap around the base of the inflorescence, but the total bag volume was $\sim 40 \mathrm{~L}$, so the dilution effect would have been at most $\sim 30 \%$.

\subsection{Aerosol mass spectrometer}

An Aerodyne high-resolution time-of-flight aerosol mass spectrometer (HR-ToF-AMS) was used to monitor the composition of non-refractory sub-micron PM at the oil palm plantation. The HR-ToF-AMS has been described in detail in DiCarlo et al. (2006) and is a further development of the original Aerodyne quadrupole aerosol mass spectrometer (Jayne et al., 2000; Jimenez et al., 2003). The ambient air was sampled down a $15 \mathrm{~m} 1 / 4^{\prime \prime}$ stainless steel inlet tube and 
sub-sampled by the AMS via a Nafion drier. The inlet was situated next to the sonic anemometer just above the oil palm canopy co-located with the PTR-MS. The AMS uses an aerodynamic lens in a differentially-pumped vacuum chamber to enhance the aerosol mass over the gas in the sample. The aerosol was vaporised at $600^{\circ} \mathrm{C}$ and extracted into the $\mathrm{ToF}$ mass spectrometer.

The instrument was operated in the general alternation mode, switching between the MS/PToF mode and the high resolution MS modes every 5 min every other half hour. The remaining half hour was used for eddy-covariance flux measurements not presented in this paper. The data analysis was performed using SQUIRREL, the standard ToF-AMS analysis suite developed by the Universities of Manchester and Colorado and Aerodyne Research and hosted electronically at the University of Colorado at Boulder ${ }^{2}$. Here only parts of the dataset are used, with a more detailed analysis of the aerosol composition and fluxes provided by Nemitz et al. (2010).

\subsection{Parameterisations for estragole emission}

There are many algorithms for modelling foliar emissions of BVOCs, some of which have been incorporated into models such as MEGAN (Guenther et al., 2006). The potential importance of floral emissions for atmospheric chemistry was recognized by Arey et al. (1991) who report linalool concentrations in an orange tree plantation that are of a similar magnitude to the estragole concentrations observed in this study. However, floral emissions have not been included as a component of regional biogenic emission models due to both the limited quantitative emission rate data and the lack of suitable driving parameters. As a result, it is not known what contribution they make to canopy emission. However, oil palms occupy a large land area, and as we show, the contribution of estragole emissions to total BVOCs can be very high. The actual estragole release and its magnitude are likely to be constrained by biological factors related to the pollination cycle. Temperature of vegetative surfaces can be different from ambient temperature above the canopy, and therefore it is important to use the former in the parameterisations.

Canopy temperature $\left(T_{\mathrm{c}}\right)$, as estimated from the resistance approach (Eq. 1), was generally higher by approximately $2{ }^{\circ} \mathrm{C}$ during midday and lower by $0.2^{\circ} \mathrm{C}$ during the night than $T_{\mathrm{a}}$ (the ambient temperature at the $15 \mathrm{~m}$ sensor height).

$T_{\mathrm{c}}=T\left(z_{0}^{\prime}\right)=T_{\mathrm{a}}\left(z_{\mathrm{m}}\right)+\frac{H\left(R_{\mathrm{a}}\left(z_{\mathrm{m}}\right)+R_{\mathrm{b}}\right)}{\rho c_{\mathrm{p}}}$

Here $H$ is the sensible heat flux, $R_{\mathrm{a}}\left(z_{\mathrm{m}}\right)$ is the aerodynamic resistance, $R_{\mathrm{b}}$ is the laminar boundary layer resistance close to the surface of the leaves, $\rho$ is air density, and $c_{\mathrm{p}}$ is the specific heat of air.

\footnotetext{
${ }^{2}$ http://cires.colorado.edu/jimenez-group/ToFAMSResources/ ToFSoftware/index.html
}

Since estragole may also exhibit occasional deposition, for the highest accuracy atmospheric models would either need to consider this as a loss of part of the emission flux or by including this compound in deposition models. The available data for validated measured deposition are insufficient for the implementation of the canopy resistance analogy (Nemitz et al., 2009; Sutton et al., 1995), in which the overall modelled flux is represented as:

$F_{\text {net }}=F^{+}-V_{\mathrm{d}}(z) \chi\left(z_{\mathrm{m}}\right)$

where $F_{\text {net }}$ is the net flux above the canopy, $F^{+}$is the parameterised emission from the vegetation, $V_{\mathrm{d}}(z)$ is the parameterised deposition velocity, and $\chi\left(z_{\mathrm{m}}\right)$ is the concentration measured. For this modelling exercise we limit the investigation only to modelling emission flux $\left(F^{+}\right)$(Eq. 3) and we neglect deposition $\left(-V_{\mathrm{d}}(z) \chi\left(z_{\mathrm{m}}\right)\right)$, which is likely to be minor in relation to the emission of estragole.

$F^{+}=\mathrm{BER}_{\mathrm{c}} \cdot \gamma_{T} \cdot \gamma_{P}$

$\mathrm{BER}_{\mathrm{c}}$ is the canopy-derived basal emission rate (for standard conditions) which can be obtained from Eq. (3) by substituting $F^{+}$with the eddy covariance flux above the canopy (filtered to exclude deposition periods), $\gamma_{T}$ and $\gamma_{P}$ are the temperature and PAR activity factors, respectively, compensating for changes in emission due to deviations from standard conditions:

$$
\begin{aligned}
& \gamma_{P}=C_{P}\left[(\alpha \cdot \mathrm{PAR}) /\left(\sqrt{1+\alpha^{2} \cdot \mathrm{PAR}^{2}}\right)\right] \\
& \gamma_{T}=E_{\mathrm{opt}} \cdot \frac{\mathrm{C}_{T 2} \cdot \exp \left[\mathrm{C}_{T 1} \cdot\left(\frac{1}{T_{\mathrm{opt}}}-\frac{1}{T}\right) \cdot \frac{1}{0.00831}\right]}{\mathrm{C}_{T 2}-\mathrm{C}_{T 1} \cdot\left[1-\exp \left(\mathrm{C}_{T 2} \cdot\left(\frac{1}{T_{\mathrm{opt}}}-\frac{1}{T}\right) \cdot \frac{1}{0.00831}\right)\right]}
\end{aligned}
$$

where $C_{P}, \alpha, E_{\mathrm{opt}}$, and $T_{\mathrm{opt}}$ can be expanded further:

$$
\begin{aligned}
& \alpha=\mathrm{b}_{1}-\mathrm{b}_{2} \ln \left(P_{240}\right) \\
& C_{P}=\mathrm{b}_{3} \cdot \exp \left[\mathrm{b}_{2} \cdot\left(P_{24}-P_{0}\right) \cdot\left(P_{240}\right)^{0.6}\right] \\
& T_{\mathrm{opt}}=T_{\mathrm{b}}+\left[\mathrm{b}_{4} \cdot\left(T_{240}-297\right)\right] \\
& E_{\mathrm{opt}}=\mathrm{b}_{5} \cdot \exp \left[\mathrm{b}_{6} \cdot\left(T_{24}-297\right)\right] \cdot \exp \left[\mathrm{b}_{6} \cdot\left(T_{240}-297\right)\right]
\end{aligned}
$$

In the above equations PAR and $T$ are photosynthetically active radiation $\left(\mu \mathrm{mol} \mathrm{m} \mathrm{m}^{-2} \mathrm{~h}^{-1}\right)$ and leaf temperature $(\mathrm{K})$, respectively. The latter was approximated by deriving $T_{\mathrm{c}}$ (Eq. 1)

In the formalism of the G06 algorithm (Guenther et al., 2006), $F^{+}$(Eq. 3) is a function of the lag-adjusted ambient temperature $(T)$ and photosynthetically active radiation (PAR). The G06 algorithm is an advanced emission model simulating direct canopy scale emission $\left(\mathrm{mg} \mathrm{m}^{-2} \mathrm{~h}^{-1}\right)$ rather than the emission per dry leaf mass, as it has an integrated canopy environmental model. The G06 algorithm for isoprene is essentially similar to the earlier Guenther algorithms 
(Guenther et al., 1993, 1995, 1999), except that many empirical parameters, which used to have prescribed constant values (e.g. $C_{P}, \alpha, E_{\text {opt }}$ and $T_{\text {opt }}$ ) have been expanded to contain more parameters specific to the simulation of variations in isoprene emission in response to previous PAR and temperature history, which is related to the changes in enzyme-driven substrate synthesis for isoprene and phosphorylation dependent on ATP availability. The actual parameters in the original model derive from a number of measurements, where isoprene light and temperature responses as affected by many factors (PAR and temperature history, response to $\mathrm{CO}_{2}$ or ozone, and enzymatic kinetics) were studied (e.g. Geron et al., 2000; Hanson and Sharkey, 2001; Monson et al., 1994; Petron et al., 2001; Sharkey et al., 1999). Because of such diversity in empirical parameters this algorithm has many degrees of freedom, which was one of the reasons for its choice for fitting the measured estragole canopy flux. Since no light and temperature responses to estragole floral emissions are available, the parameters were constrained to a restricted range, so the fitted values of these parameters should be treated with caution in inferring any physiological significance.

Although the formalism of the Guenther et al. (2006) approach has been adopted, the fitted empirical constants were derived from the measurement data for estragole eddy covariance fluxes at the site. The Eqs. (3-9) were merged into one large equation and overall 10 empirical constants were optimised using the estragole flux data in order to achieve the best fit. The comparison between original and modified parameters is given in Table 3.

\section{Results and discussion}

\subsection{Estragole mixing ratios}

\subsubsection{Specificity for oil palm and screening for anisoles}

Estragole, being p-allyl-anisole, belongs to the family of anisole compounds whose structure includes a methoxy group attached to a benzene ring. Emission of aromatic compounds, not from anthropogenic sources but from vegetation, is very interesting from a biochemical point of view, but there are very few published data. Toluene is an example of a typical anthropogenic compound which can be emitted by some plants (Heiden et al., 1999; White et al., 2009). During measurements in Borneo, estragole was only found at the oil palm plantation, and it was not detected either above a rainforest canopy or in the screening of individual tree foliage in the rainforest. In fact, in the rainforest, anisole and many of its derivatives (e.g. p-vinyl-anisole, p-ethyl-anisole, p-ethylene-anisole) were detected lower in the canopy by PTR-MS, but not p-allyl-anisole (estragole), neither below nor above canopy.
By comparison, in the oil palm ambient air, estragole, but none of its derivatives, was the second most abundant measured VOC after isoprene. The chromatogram of oil palm ambient air (Fig. 2) reveals that the peak of estragole dominates the signal. The isoprene peak is not shown in this retention-time range. It is worth noting that the high abundance of estragole in the ambient air above the oil palm canopy was recorded by both PTR-MS and GC-MS, while the leaf-cuvette study detected only very small concentrations of estragole and in only a few percent of the samples, even using a measurement system that provides an upper estimate of emission fluxes (see Sect. 2.3.1). This clearly indicates that estragole is not primarily emitted by the fronds, but almost certainly is released by the flowers, which is not surprising, given its role in pollination. As leaf surfaces can adsorb and store significant amounts of deposited gases (Binnie et al., 2002) it is likely that small emissions from fronds are secondary to previous deposition, which was quite frequent for this semi-volatile compound. Due to the fact that sampling was not directly from the flowers, one might argue about possible different sources (e.g. fruit, stems, etc.). Nevertheless, estragole has an intense aniseed scent and from observation of the weevil's role in pollination it seems apparent that it is attracted to the flower (Mahbob, 2008). Neither fruit nor leaves had an obvious smell of aniseed. See Sect. 3.4 (below).

\subsubsection{Diurnal cycles}

Results from the leaf emission samples and random ambient air samples for analysis by GC-MS are presented in Table 1. The time series for estragole mixing ratios recorded by PTRMS is shown in Fig. 3 and the diurnal average is presented in Fig. 4a in comparison with temperature and PAR. In addition, the box-and-whisker plot in Fig. 4b illustrates its dayto-day variability. The estragole diurnal cycles may provide information on feeding/pollinating times of the insect. Estragole mixing ratios moderately correlate with temperature corrected by a lag of $\sim 3.5 \mathrm{~h}$, suggesting a short-term storage pool in the plant before release a few hours later. It is possible that estragole accumulates later in the evening in the collapsing boundary layer, but its flux is not picked up by the eddy covariance flux due to insufficient turbulence at those times.

The estragole mixing ratio from PTR-MS was moderately correlated with the $3.5 \mathrm{~h}$ lag-adjusted temperature $\left(r^{2}=0.4\right)$ and the $4.5 \mathrm{~h}$ lag-adjusted PAR $\left(r^{2}=0.34\right)$, but without a lag correction no correlations were found. This is different for the case of other VOCs (e.g. isoprene), whose responses to temperature (or PAR) were almost instantaneous. Based on the mass scan $(\mathrm{m} / \mathrm{z} 21-205)$ performed on the PTR-MS every hour the highest correlations between estragole normalised signal at $\mathrm{m} / \mathrm{z} 149$ were found with $\mathrm{m} / \mathrm{z} 95\left(r^{2}=0.38\right), \mathrm{m} / \mathrm{z}$ $75\left(r^{2}=0.33\right), m / z 47\left(r^{2}=30\right)$ and $m / z 121\left(r^{2}=0.24\right)$, which could be due to internal fragmentation. There were also 
Table 1. Comparison of estragole volume mixing ratios.

\begin{tabular}{|c|c|c|c|c|c|}
\hline Site/date/source & $\begin{array}{l}\text { PTR-MS } \\
\text { (ambient } 15 \mathrm{~m} \text { ) }\end{array}$ & $\begin{array}{l}\text { GC-MS (flower } \\
\text { enclosure) }\end{array}$ & GC-MS (ambient) & GC-MS (leaf) & $\begin{array}{l}\text { PTR-MS/GC- } \\
\text { MS/TAG } \\
\text { ( } 9.3 \text { m above } \\
\text { the ground) }\end{array}$ \\
\hline $\begin{array}{l}\text { Borneo (Oil palm) / } \\
29-05-2008-11 / 06 / \\
2008 \text { (this work) }\end{array}$ & $\begin{array}{l}3.0 \mathrm{ppbv}^{\mathrm{a}} \\
\left(3.0 \mathrm{ppbv}^{\mathrm{b}}\right)\end{array}$ & & & & \\
\hline $\begin{array}{l}\text { Borneo (Oil palm) / 25- } \\
05-2008 \text { (this work) }\end{array}$ & & & $\begin{array}{l}1.2 \mathrm{ppb} \text { (morning 9:00 } \\
\text { to } 10: 00 \text { ) } \\
3.0 \mathrm{ppb} \text { (early afternoon } \\
12: 00 \text { to } 14: 00 \text { ) } \\
3.8 \mathrm{ppb} \text { (late afternoon } \\
14: 00 \text { to } 16: 00 \text { ) }\end{array}$ & $<0.2 \mathrm{ppbv}$ & \\
\hline $\begin{array}{l}\text { Blodget Forest (pon- } \\
\text { derosa pine)/ (Bouvier- } \\
\text { Brown et al., 2009a; } \\
\text { Bouvier-Brown et al., } \\
2009 \mathrm{~b})\end{array}$ & & & & & $\begin{array}{l}\text { few pptv - } \\
0.5 \text { ppbv }\end{array}$ \\
\hline $\begin{array}{l}\text { Borneo }(\text { Oil palm }) / \\
15 / 5 / 2009-17 / 5 / 2009 / \\
\text { this work }\end{array}$ & & $\begin{array}{l}\text { Female flowers } \\
\sim 0.26-1.39 \mathrm{ppm}^{\mathrm{c}} \\
\left(60 \mathrm{ppm}^{\mathrm{d}}\right) \\
\text { Male flowers } \sim 150 \\
\text { ppb }\end{array}$ & & & \\
\hline
\end{tabular}

${ }^{a}$ mean over the measurement period $(\mathrm{N}=537)^{\mathrm{b}}$ if only the VMR points corresponding to periods of validated flux were taken into account $(N=109),{ }^{\mathrm{c}}$ accumulated in the enclosure ( $\sim 0 \mathrm{~L}$ headspace) ${ }^{\mathrm{d}}$ it might be possible that the tube touched the flower.

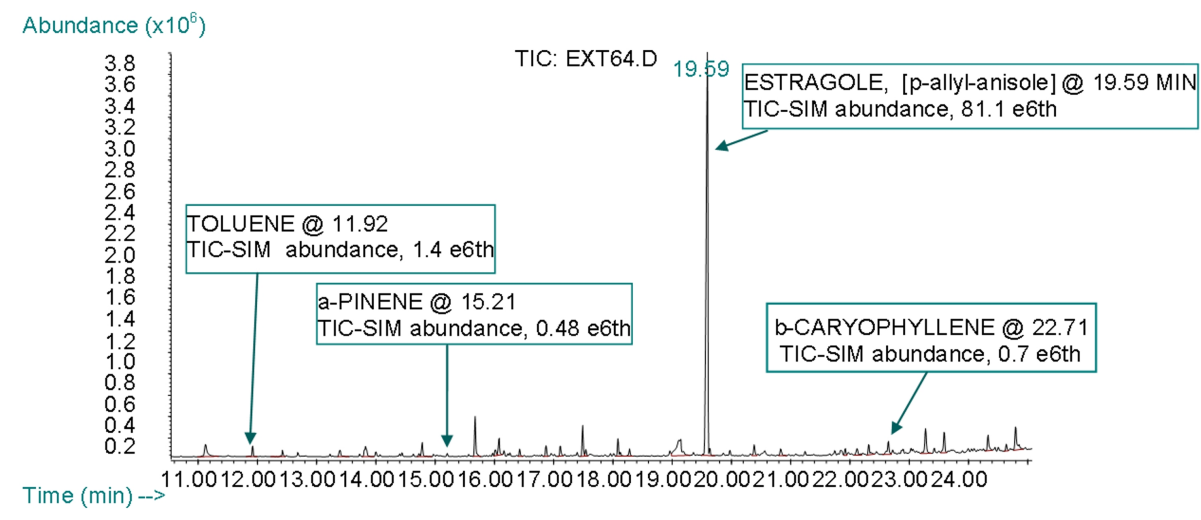

Fig. 2. Chromatogram of ambient air sampled within the oil palm canopy, showing a high abundance of estragole (p-allyl-anisole) but not of any of its derivatives. Oil palm plantation ambient air at ground level sampled on 25 May 2008. $15 \mathrm{~m} / \mathrm{z}$ ions monitored.

weak correlations with some other $\mathrm{m} / \mathrm{z}$ values representing biogenic compounds $\left(r^{2}<0.2\right)$. The latter would be higher after applying the time lag of $3.5 \mathrm{~h}$.
It is common for some fragmenting compounds (e.g. isoprene) to deviate from the relative transmission curve but it was assumed that fragmentation of estragole was not significant. The uncertainty of such an empirical sensitivity approach lies between the error of calibration with a standard (typically 5-10\%) and the error of deriving the mixing ratios 


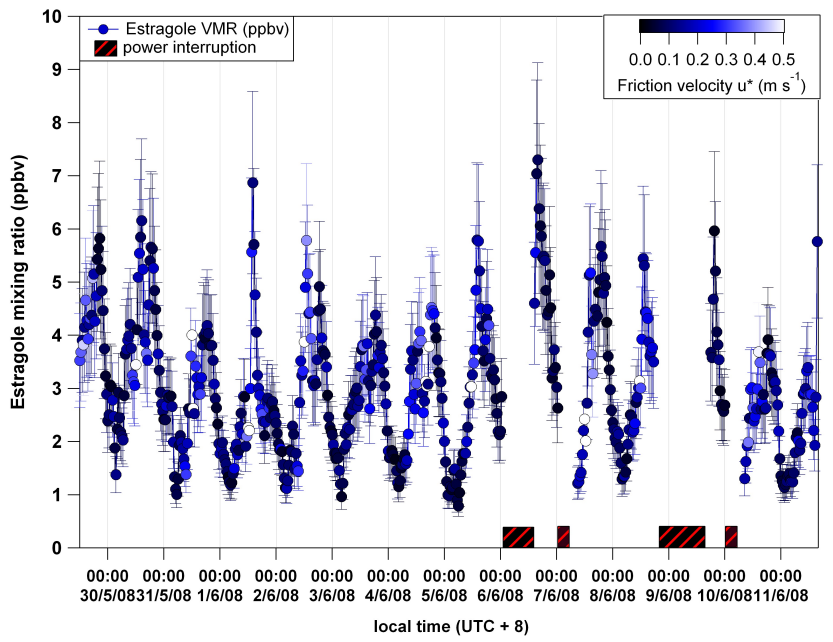

Fig. 3. Time-series of volume mixing ratios (ppbv) of estragole measured by PTR-MS above the oil palm canopy (local time [UTC+8]). The dots are coloured by friction velocity $\left(u_{*}\right)$ to show that potentially large fluxes likely occurring later in the day could be missed out in eddy covariance because of low values of $u_{*}$ (corresponding to black - dark blue). Error bars denote an estimated 30\% error in obtaining VMRs using an empirical sensitivity derived from relative transmission (see Sect. 2.2).

from drift tube reaction kinetics and proton transfer reaction rate constants (up to $100 \%$ ) (e.g. Steinbacher et al., 2004) and was estimated at $30 \%$ by Taipale et al. (2008).

\subsection{Estragole fluxes}

Previous PTR-MS measurements over Ponderosa pines ( $\mathrm{Pi}$ nus ponderosa) showed concentrations of estragole to correlate closely with 2-methyl-3-butenol (MBO) (BouvierBrown et al., 2009a, b; Holzinger et al., 2005). However, MBO was not observed at the oil palm plantation, implying different biochemistries of conifer leaf and oil palm floral emissions. Therefore the method suggested by BouvierBrown et al. (2009a) for inferring estragole emissions from correlations with MBO is not applicable for oil palm. A comparison of fluxes reported from other environments is shown in Table 2. The observed fluxes above oil palms are the highest reported so far, and for the first time reported from tropical oil palms. The flux time series is presented in Fig. 5 in relation to canopy temperature $\left(T_{\mathrm{c}}\right)$, which is the most likely driver for estragole emission (or deposition). Estragole net emission can be decreased by periods of estragole deposition, which can be affected by delayed temperature response, and local gradients caused by possibly slightly different release times of particular inflorescences. Night time emission and deposition are uncertain as the flux was generally below the detection limit and the turbulence was insufficient ( $\operatorname{small} u_{*}$ ). However, the small estragole concentrations observed in the shallow night-time boundary layer confirm that night-time
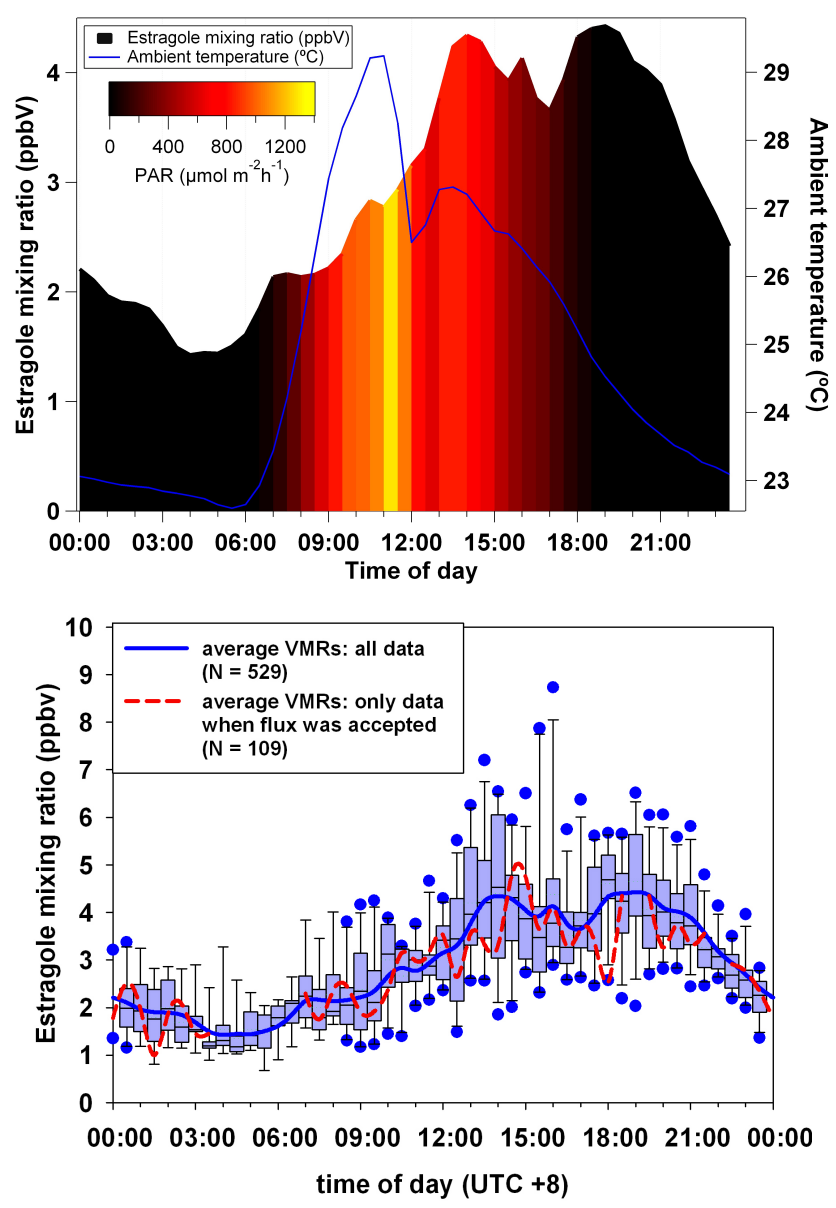

Fig. 4. Average diurnal cycles of estragole mixing ratios (left axis): (a) average in relation to temperature (right axis) and PAR (colour scale); (b) Box-and-Whisker plot of day-to-day variability, showing averages (blue line), median with 25th and 75th percentile (box), 5 th and 95th percentiles (whiskers) and outliers (dots).

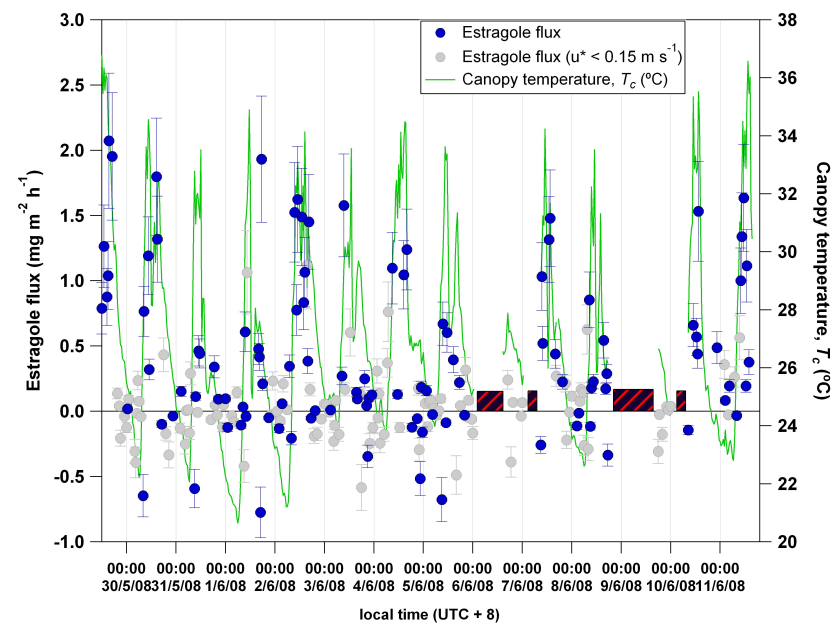

Fig. 5. Estragole flux with uncertainty bars (mean error estimated at $35 \%$ ), and canopy temperature. Black/red areas refer to power interruptions. 
Table 2. Comparison of estragole fluxes.

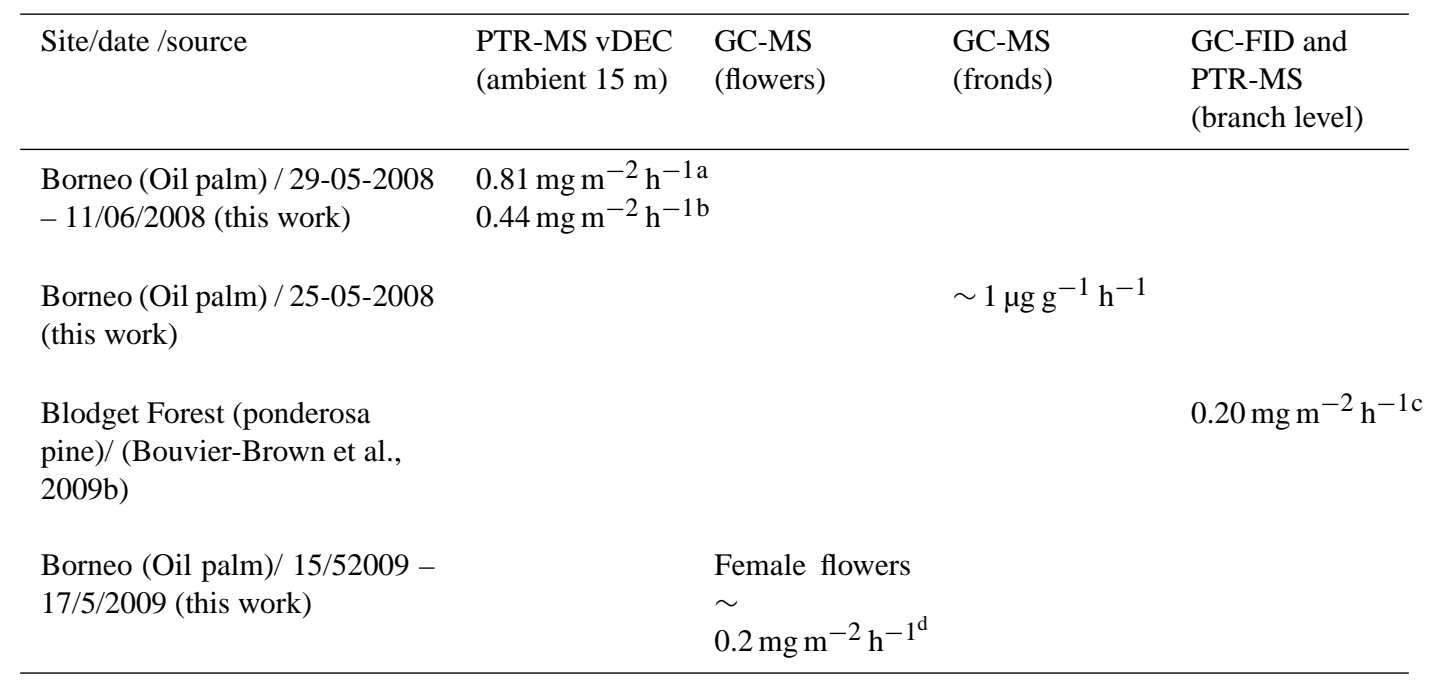

a mid-day mean 10:00-14:00 $(N=26)$; b 24 -h average of 12 days of validated flux $(N=109)^{\mathrm{c}}$ converted from basal rate of $1.37 \mu \mathrm{mol} \mathrm{m}{ }^{-2} \mathrm{~h}^{-1}$ (Bouvier-Brown et al., 2009a); ${ }^{\mathrm{d}}$ expected to be underestimated (explanation in Sect. 3.4); the value was estimated assuming 150 trees $^{-1}$ average global density although the actual density at the site was smaller $\left(124\right.$ trees ha $\left.^{-1}\right)$.

Table 3. Comparison of empirical constants between G06 for isoprene and modified G06 for estragole.

\begin{tabular}{|c|c|c|c|}
\hline Parameter & Type of activity factor & Original G06 for isoprene & Modified G06 for estragole \\
\hline $\mathrm{C}_{T 1}$ (Eq. 5) & $\gamma_{T}$ & 95 & 131 \\
\hline $\mathrm{C}_{T 2}$ (Eq. 5) & $\gamma_{T}$ & 542 & 230 \\
\hline $\mathrm{b}_{1}$ (Eq. 6) & $\gamma_{P}$ & 0.004 & 0.031 \\
\hline $\mathrm{b}_{2}$ (Eqs. 6,7$)$ & $\gamma_{P}$ & 0.0005 & 0.0030 \\
\hline $\mathrm{b}_{3}($ Eq. 7$)$ & $\gamma_{P}$ & 0.0468 & 0.0453 \\
\hline $\mathrm{b}_{4}$ (Eq. 8) & $\gamma_{T}$ & 0.6 & -0.32 \\
\hline $\mathrm{b}_{5}$ (Eq. 9) & $\gamma_{T}$ & 2.034 & 1.812 \\
\hline $\mathrm{b}_{6}$ (Eq. 9) & $\gamma_{T}$ & 0.05 & -0.21 \\
\hline $\mathrm{T}_{\mathrm{b}}$ (Eq. 8) & $\gamma_{T}$ & $313 \mathrm{~K}$ & $307 \mathrm{~K}$ \\
\hline$P_{0}$ (Eq. 7) & $\gamma_{P}$ & $\begin{array}{l}200 \mu \mathrm{mol} \mathrm{m}{ }^{-2} \mathrm{~s}^{-1} \text { (sun leaves) } \\
50 \mu \mathrm{mol} \mathrm{m}{ }^{-2} \mathrm{~s}^{-1} \text { (shade leaves) }\end{array}$ & $200 \mu \mathrm{mol} \mathrm{m}{ }^{-2} \mathrm{~s}^{-1}$ \\
\hline
\end{tabular}

emissions are very small. The highest fluxes were normally observed during the middle of the day, peaking at approximately $2 \mathrm{mg} \mathrm{m}^{-2} \mathrm{~h}^{-1}$. There were also periods of apparent deposition for estragole, which is, however, less certain being often at the edge of the rejection thresholds and could be driven by varying gradients caused by different opening times of male and female flowers. On the averaged diurnal graph (Fig. 6a) one can see the estragole flux in comparison with $T_{\mathrm{c}}$ and PAR (on the colour scale). Although in the mixing ratios there was a delayed correlation observed with temperature, it seems that there is not a large shift in the flux compared with the $T_{\mathrm{c}}$ but the afternoon peak is disproportionally higher in relation to $T_{\mathrm{c}}$ and PAR. This is because most of the flux is transported by turbulent eddies, and thus as soon as mixing within the PBL decreases it appears that there is an accumulation of estragole, which slowly decays overnight. However, also because of the laminar conditions it is possible that the true flux at night time might not be captured by eddy covariance. It would be interesting to study if estragole can be taken up by palms during the night, whether it can penetrate into the soil, and to better understand its ventilation and chemistry at night. The Box-and-Whisker plot in Fig. 6b shows high day-to-day variability, probably due to periods of deposition but also because the strength of the particular flower sources operating in a 5 day pollination cycle (Syed, 1979) can be varied as more flowers on the spikelets/inflorescences are becoming active/inactive. 

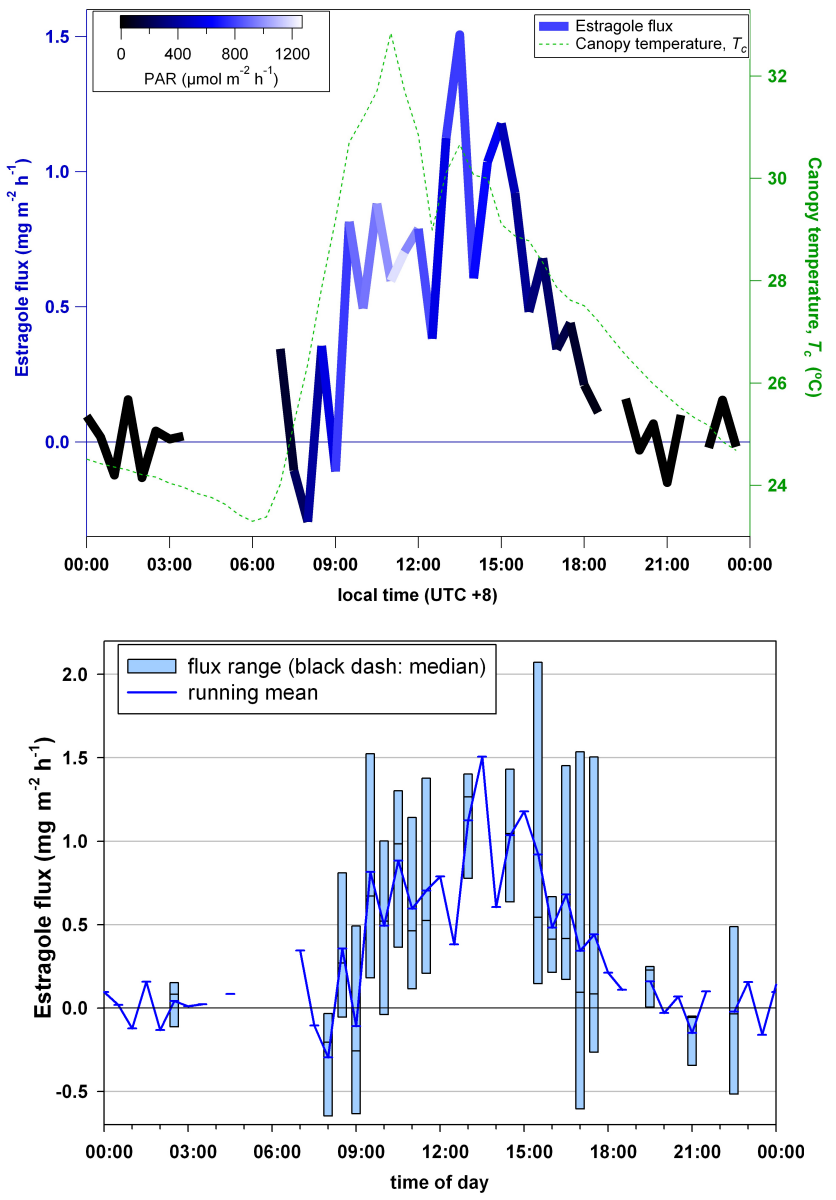

Fig. 6. Average diurnal cycles of the estragole flux: (a) in comparison with canopy temperature (right axis), and shaded by PAR; (b) Box-and-Whisker plots showing day-to-day variability.

\subsection{Contribution of estragole from oil palms to global emissions}

The 24-h average canopy flux of estragole for the period 29 May-11 June 2008 (12 days of measurement) including both emission and deposition was $0.44 \mathrm{mg} \mathrm{m}^{-2} \mathrm{~h}^{-1}$. Given the total area of oil palm plantations worldwide of 13.9 million hectares (FAO, 2009) and assuming that this net flux is representative for the annual average (oil palms produce flowers and fruit all year) this average flux would yield $535 \mathrm{Gg}\left(10^{9} \mathrm{~g}\right)$ of globally emitted estragole per year, with the regional 60\% contribution for Indonesia and Malaysia of $321 \mathrm{Gg} \mathrm{y}^{-1}$. This is a very large flux in terms of regional contribution, and probably the highest global floral emission source, which is however three orders of magnitudes lower than estimates of global isoprene emission.

\subsection{Investigating emissions of estragole from male and female inflorescences of oil palm}

A semi-quantitative approach was used to confirm that oil palm flowers are indeed the source of estragole in the atmosphere above oil palm plantations. Six different inflorescences which were typical in appearance and health (based on visual inspection) were randomly selected for enclosures within a commercial oil palm plantation. Three inflorescences were male, and three were female.

Female inflorescences yielded estragole concentrations in the sample tubes ranging from 0.31 to $1.69 \mu \mathrm{g} \mathrm{L}^{-1}$ taking account of the approximate $50 \%$ free air-space in the 80-litre bag, which accumulated in the static enclosure over the sampling periods. This corresponds to an accumulated concentration over an hour ranging from $\sim 0.26$ to $1.39 \mathrm{ppm}$. Concentrations were higher in the morning than later in the day. However, the third female inflorescence gave sample concentrations which were in excess of $77 \mu \mathrm{g} \mathrm{L}^{-1}$ in the morning $(\sim 60 \mathrm{ppm})$. It is possible that the sample tubes for this female flower actually touched the source of estragole in the inflorescence, and contaminated the steel case. In contrast, male inflorescences gave lower concentrations in the sample tubes ranging from 0.02 to $0.18 \mu \mathrm{g} \mathrm{L}^{-1}$ (up to $\sim 0.15 \mathrm{ppm}$ ). Concentrations tended to be higher in the middle part of the day. Generally, male and female inflorescences weigh about $0.5 \mathrm{~kg}$ and $1 \mathrm{~kg}$, respectively. Therefore differences in mass do not entirely account for the different concentrations found in samples from male and female inflorescences. Because the concentrations in some of the samples saturated the GC-MS detector, it is likely that the true concentrations are underestimated by an unknown factor.

The concentrations of estragole were assumed to accumulate over the sampling period, and therefore an approximate emission rate from each inflorescence could be estimated simply by dividing the concentration $\left(\mu \mathrm{gL}^{-1}\right)$ by time (h) to give emission rates expressed as ( $\mu$ g estragole inflorescence ${ }^{-1} \mathrm{~h}^{-1}$ ). It is recognised that size of inflorescence varies, and at best, these estimates are semiquantitative with the aim of showing that oil palm flowers were a significant source of estragole. Consequently, although it is not possible to report accurate quantitative fluxes of estragole from oil palm flowers, if an average of $15 \mathrm{fe}-$ male inflorescences per tree is assumed, and a global planting density of 150 trees $\mathrm{ha}^{-1}$, one derives a semi-quantitative estimate of up to $0.2 \mathrm{mg} \mathrm{m}^{-2} \mathrm{~h}^{-1}$ emission of estragole from female flowers. The actual density of palms at the measurement site was 124 trees ha ${ }^{-1}$, so lower than recommended by FAO. The flux upscaled from enclosures is approximately half of the total-flux value derived from the PTR-MS $\left(0.44 \mathrm{mg} \mathrm{m}^{-2} \mathrm{~h}^{-1}\right)$. This could be explained by the different sampling period, underestimation of flux from GC cartridges due to detector saturation (see above) or enclosure sampling losses. However, this confirms that oil palm flowers are the most likely source of the estragole in the atmosphere 


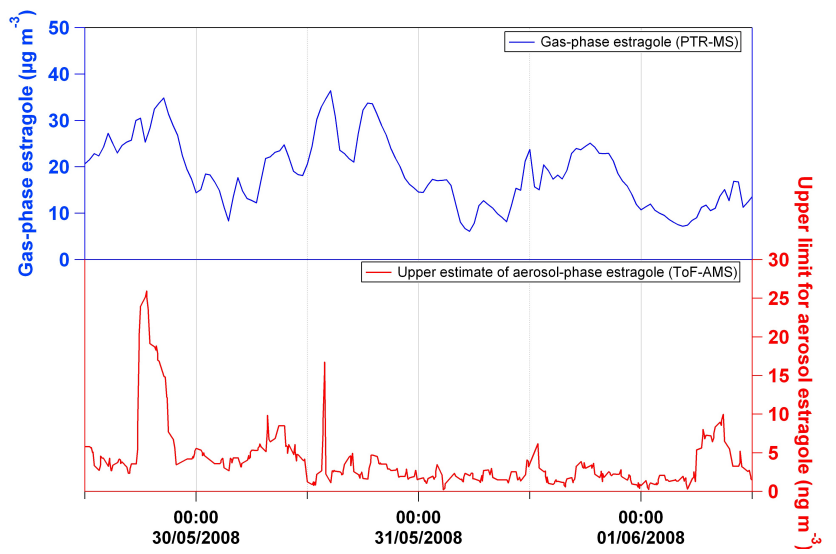

Fig. 7. Estragole in gas phase as measured by PTR-MS (blue) and upper limit in the aerosol phase (measured by AMS) as estimated from typical fragmentation patterns for estragole.

above oil palm plantations, although the possibility of another source within the plantation biota cannot be excluded.

\subsection{Estragole partitioning in the aerosol phase}

Estragole has a relatively high aerosol partition coefficient, $\log K_{\text {oa }}$ octanol-air partition coefficient of 5.194, as estimated by KOAWIN ${ }^{\mathrm{TM}} \mathrm{v} 1.10$ (EPA, 2007), and in certain conditions can partition into the aerosol phase. To evaluate whether estragole could be detected with the HR-ToFAMS, nebulised estragole was sampled into the instrument under laboratory conditions, with the main peaks at $\mathrm{m} / \mathrm{z} 53$ (2), 70 (10), 77 (10), 91 (10), 115 (8) and 147 (6), selected as likely fragments for estragole aerosol). In brackets are given relative percentages of the most dominant peak at $\mathrm{m} / \mathrm{z}$ 15. This peak could be the methyl fragment disconnected from the chavicyl ether moiety, but it was not included in the list of potential estragole fragments due to expected contributions at this $\mathrm{m} / \mathrm{z}$ from other compounds. Although, under field conditions, each of these peaks has contributions from many other compounds, an upper estimate of the aerosol estragole concentration can be obtained by summing the signals at these $\mathrm{m} / \mathrm{z}$. A ratio of the fragment sum for estragole and $m / z \quad 15(0.46)$ was used to convert to the actual estragole concentrations (in $\mu \mathrm{g} \mathrm{m}^{-3}$ ) and thus potentially leading to an additional overestimation due to likely contributions from other sources at the plantation. For this reason, the absolute values for aerosol estragole should be treated as a total upper threshold of an estimate. In Fig. 7 the comparison between this upper estimate of estragole in the aerosol phase and the PTR-MS gas-phase measurement is presented. The morning peak, related to a rise in aerosol fraction, can be seen on particular days by AMS and the late peak is generally dominated by PTR-MS. Overall, the gas phase concentration exceeds the potential aerosol mass by a factor of $1 \times 10^{3}$ to $1 \times 10^{4}$, which cannot be determined more accurately from the available data.

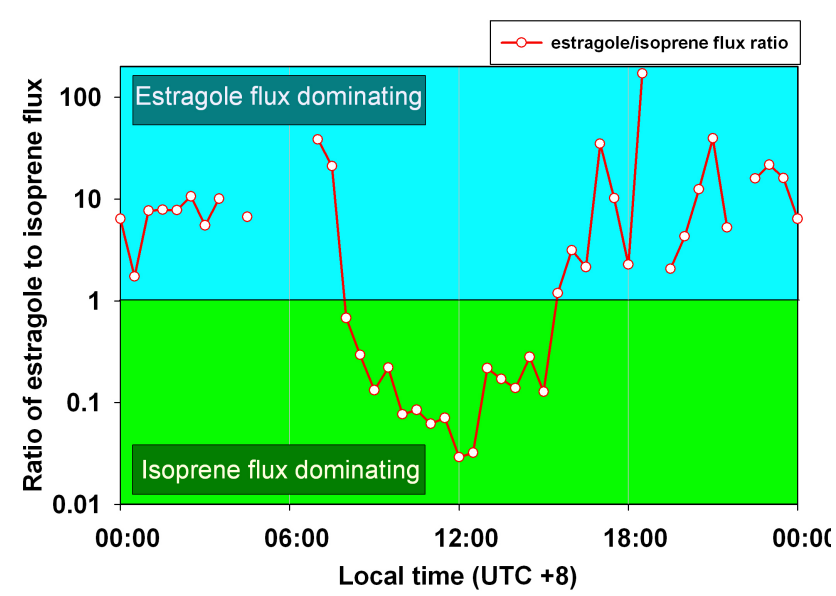

Fig. 8. Diurnal trend of the ratios of estragole to isoprene flux, showing the morning and afternoon times when estragole flux dominated over the isoprene flux, which was very high during the day. The fluxes of these two compounds had similar values at around 08:00 and 15:30 h local time (UTC+8).

\subsection{Parameterisations for estragole flux}

It is worth noting the uniqueness of estragole emissions, for example in comparison with isoprene, which was the most abundant BVOC at the plantation and whose response to temperature and PAR was instantaneous rather than delayed. In Fig. 8 the ratio of estragole to isoprene flux is presented on a diurnal graph, which shows the dominance of isoprene emissions during midday, whereas estragole flux takes over after about 15:30 h. This skewness of estragole emission response to PAR and temperature towards later in the day placed severe constraints on the parameterisation using empirical method such as the G06 algorithm. The modelled emission is compared with the measured flux in Fig. 9. The modelled flux was derived as described in Sect. 2.5 with the fitted parameters given in Table 3. As the measured canopy flux is the net eddy covariance flux, a part of this predominantly positive (upward) flux may be lost in deposition. In the case of estragole some deposition can be expected due to the nature of the molecule, its lifetime, and because of several validated deposition points from a larger pool of the points that did not pass the quality criteria (for example night time or rain episodes). Detailed modelling would require the deposition term or loss-in-emission term to be included in the model so that the net flux escaping the canopy is appropriately represented. A first attempt was made to estimate the actual total loss in emission by inclusion of a deposition term following the resistance approach of Eq. (2), which was fitted to the available deposition data (not shown). The deposition component was relatively small $(16.5 \%$ of the total flux) and is subject to large uncertainties mainly related to the small number of validated deposition points used in deriving mean $R_{\mathrm{c}}$ and our lack of mechanistic understanding of 


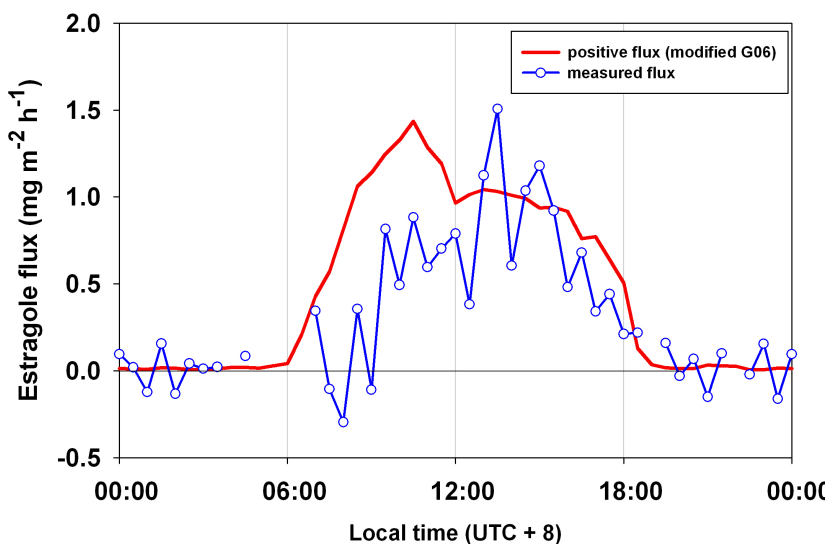

Fig. 9. Diurnal patterns for measured estragole flux (blue) in relation to modelled emission by modified G06 (red).The current G06 algorithm is unable to accurately represent the second peak of estragole (occurring at 13:00-18:00 h), which could be due to possible thermogenesis and/or specific circadian control of emission. The whole dataset was used to constrain the algorithm, so that the morning peak is overestimated by the modelled emissions.

the deposition pathways.

The overall average of the total flux predicted by the emission-only model amounted to $0.49 \mathrm{mg} \mathrm{m}^{-2} \mathrm{~h}^{-1}$ which is only $0.05 \mathrm{mg} \mathrm{m}^{-2} \mathrm{~h}^{-1}$ higher than the actual measurement. Although the parameterised emission for isoprene gave an almost identical fit with measurements above the canopy (Misztal et al., 2010), the same parameterisation for estragole was unable to fully resolve the late peak of emissions, which is underestimated and which in turn results in an overestimation of the morning peak of emissions due to the G06algorithm parameters being constrained by the whole measurement dataset. Nevertheless, bearing in mind that flowers are governed by different, often complex, mechanisms from leaves with stomata (e.g., different production, mechanical release), the overall agreement is rather impressive. This could be further improved if the model was adjusted to contain other factors such as thermogenesis.

It is possible that inflorescences of E. guineensis are thermogenic as has been reported for other oil palm species (Knudsen et al., 2001). Thermogenesis presumably helps to volatilise floral scents (in this case estragole) and serves as a cue for pollinators (Ervik et al., 1999). However, although not explicitly tested during this study, thermogenic volatilisation after the decrease in ambient temperature could explain the delayed peak of estragole concentrations with temperature (Terry et al., 2004).

\section{Conclusions}

Using data from this study it is estimated that approximately $500 \mathrm{Gg}$ of estragole are emitted from oil palm plantations annually. Although three orders of magnitude less than global isoprene emissions from vegetation, these estragole emissions are probably the highest single floral contribution of reactive carbon to global atmospheric chemistry. Estragole is probably present also in the aerosol phase as well as the gas phase and is also subject to deposition as well as emission. Since estragole emissions are likely to make a regionally-important contribution to BSOA, whether by directly partitioning into the aerosol phase or after reacting to more condensable oxidation products, it is possible that estragole emissions may have an important influence on regional climate. Although the processes driving floral emissions are less well understood than for foliar emissions, we have shown that the former can also be described by a modification of the G06 algorithm.

A number of uncertainties accompany the above conclusions, including: a comparatively short measurement period; not always the same period of measurement for the different techniques; seasonal variations in emissions; calibration precision; flux errors; and influence of high humidity on measurement sensitivity. Despite these caveats, it is estimated that the overall measurement error should be within a factor of 2 for the PTR-MS concentrations and fluxes, smaller for the in situ GC-MS results, but much larger for data from the enclosures. Clearly, more research is required to understand the mechanisms of estragole formation, its biotic and abiotic controls, and to quantify its emission rates from other tropical species.

Acknowledgements. This work was funded by the UK Natural Environment Research Council (NERC) through the ACES (Aerosol Coupling in the Earth System) project of the APPRAISE (Aerosol Properties, PRocesses and InfluenceS on the Earth's climate) research programme. Pawel Misztal thanks his supervisors J. Neil Cape and Mathew R. Heal, and the Centre for Ecology \& Hydrology and the School of Chemistry, University of Edinburgh, for funding his $\mathrm{PhD}$. We are grateful to the Sabahmas Plantation of PPB Oil Palms Bhd., and in particular to Mr. Foo Koh Kei (senior manager) and Mr. Chang Sip Woon (group manager) for the provision of lodging, transport and site infrastructure. This is paper number 505 of the Royal Society's South East Asian Rainforest Research Programme.

Edited by: R. MacKenzie

\section{References}

Altshuller, A. P.: Review - Natural volatile organic-substances and their effect on air-quality in the United-States, Atmos. Environ., 17, 2131-2165, 1983.

Binnie, J., Cape, J. N., Mackie, N., and Leith, I. D.: Exchange of organic solvents between the atmosphere and grass - the use of open top chambers, Sci. Total Environ., 285, 53-67, 2002. 
Blake, R. S., Monks, P. S., and Ellis, A. M.: Proton-Transfer Reaction Mass Spectrometry, Chem. Rev., 109, 861-896, doi:10.1021/cr800364q, 2009.

Bouvier-Brown, N. C., Holzinger, R., Palitzsch, K., and Goldstein, A. H.: Quantifying sesquiterpene and oxygenated terpene emissions from live vegetation using solid-phase microextraction fibers, J. Chromatography A, 1161, 113-120, 2007.

Bouvier-Brown, N. C., Goldstein, A. H., Worton, D. R., Matross, D. M., Gilman, J. B., Kuster, W. C., Welsh-Bon, D., Warneke, C., de Gouw, J. A., Cahill, T. M., and Holzinger, R.: Methyl chavicol: characterization of its biogenic emission rate, abundance, and oxidation products in the atmosphere, Atmos. Chem. Phys., 9, 2061-2074, doi:10.5194/acp-9-2061-2009, 2009a.

Bouvier-Brown, N. C., Holzinger, R., Palitzsch, K., and Goldstein, A. H.: Large emissions of sesquiterpenes and methyl chavicol quantified from branch enclosure measurements, Atmos. Environ., 43, 389-401, doi:10.1016/j.atmosenv.2008.08.039, 2009b.

Buchmann, N., Guehl, J. M., Barigah, T. S., and Ehleringer, J. $\mathrm{R}$.: Interseasonal comparison of $\mathrm{CO} 2$ concentrations, isotopic composition, and carbon dynamics in an Amazonian rainforest (French Guiana), Oecologia, 110, 120-131, 1997.

Culf, A. D., Fisch, G., Malhi, Y., Carvalho Costa, R., Nobre, A. D., de O. Marques Filho, A., Gash, J. H. C., and Grace, J.: Carbon dioxide measurements in the nocturnal boundary layer over Amazonian forest, Hydrol. Earth Syst. Sci., 3, 39-53, doi:10.5194/hess-3-39-1999, 1999.

Davison, B., Taipale, R., Langford, B., Misztal, P., Fares, S., Matteucci, G., Loreto, F., Cape, J. N., Rinne, J., and Hewitt, C. N.: Concentrations and fluxes of biogenic volatile organic compounds above a Mediterranean macchia ecosystem in western Italy, Biogeosciences, 6, 1655-1670, doi:10.5194/bg-6-16552009, 2009.

de Gouw, J., Warneke, C., Karl, T., Eerdekens, G., van der Veen, C., and Fall, R.: Sensitivity and specificity of atmospheric trace gas detection by proton-transfer-reaction mass spectrometry, Int. J. Mass Spectrom., 223-224, 365-382, 2003.

DeCarlo, P. F., Kimmel, J. R., Trimborn, A., Northway, M. J., Jayne, J. T., Aiken, A. C., Gonin, M., Fuhrer, K., Horvath, T., Docherty, K. S., Worsnop, D. R., and Jimenez, J. L.: Field-deployable, high-resolution, time-of-flight aerosol mass spectrometer, Anal. Chem., 78, 8281-8289, doi:10.1021/ac061249n, 2006.

Ervik, F., Tollsten, L., and Knudsen, J. T.: Floral scent chemistry and pollination ecology in phytelephantoid palms (Arecaceae), Plant Syst. Evol., 217, 279-297, 1999.

FAOSTAT: Online Statistical Service. Item: Oil palm fruit; element: area harvested; year: 2007; country: World, South East Asia, Malaysia, Indonesia, online available at: http://faostat.fao.org (last access: April 2009), 2009.

Foken, T. and Wichura, B.: Tools for quality assessment of surfacebased flux measurements, Agr. Forest Meteorol., 78, 83-105, 1996.

Geron, C., Guenther, A., Sharkey, T., and Arnts, R. R.: Temporal variability in basal isoprene emission factor, Tree Physiol., 20, 799-805, 2000.

Geron, C., Owen, S., Guenther, A., Greenberg, J., Rasmussen, R., Hui Bai, J., Li, Q.-J., and Baker, B.: Volatile organic compounds from vegetation in southern Yunnan Province, China: Emission rates and some potential regional implications, Atmos. Environ., 40, 1759-1773, 2006.
Guenther, A., Hewitt, C. N., Erickson, D., Fall, R., Geron, C., Graedel, T., Harley, P., Klinger, L., Lerdau, M., McKay, W. A., Pierce, T., Scholes, B., Steinbrecher, R., Tallamraju, R., Taylor, J., and Zimmerman, P.: A global-model o fnatural volatile organic-compound emissions, J. Geophys. Res.-Atmos., 100, 8873-8892, 1995.

Guenther, A., Baugh, B., Brasseur, G., Greenberg, J., Harley, P., Klinger, L., Serça, D., and Vierling, L.: Isoprene emission estimates and uncertainties for the Central African EXPRESSO study domain, J. Geophys. Res., 104, 30625-30639, doi:10.1029/1999jd900391, 1999.

Guenther, A., Karl, T., Harley, P., Wiedinmyer, C., Palmer, P. I., and Geron, C.: Estimates of global terrestrial isoprene emissions using MEGAN (Model of Emissions of Gases and Aerosols from Nature), Atmos. Chem. Phys., 6, 3181-3210, doi:10.5194/acp-63181-2006, 2006.

Guenther, A. B., Zimmerman, P. R., Harley, P. C., Monson, R. K., and Fall, R.: Isoprene and monoterpene emission rate variability - model evaluations and sensitivity analyses, J. Geophys. Res.Atmos., 98, 12609-12617, 1993.

Hanson, D. T. and Sharkey, T. D.: Rate of acclimation of the capacity for isoprene emission in response to light and temperature, Plant Cell Environ., 24, 937-946, 2001.

Hartley, C. W. S.: The oil palm (Elaeis guineensis Jacq.), 3rd ed., Tropical Agriculture Series, Longman Scientific \& Technical, Harlow, 1988.

Heiden, A. C., Kobel, K., Komenda, M., Koppmann, R., Shao, M., and Wildt, J.: Toluene Emissions from Plants, Geophys. Res. Lett., 26, 1283-1286, 1999.

Helmig, D., Ortega, J., Guenther, A., Herrick, J. D., and Geron, C.: Sesquiterpene emissions from loblolly pine and their potential contribution to biogenic aerosol formation in the Southeastern US, Atmos. Environ., 40, 4150-4157, 2006.

Henderson, A.: A Review of Pollination Studies in the Palmae, Botan. Rev., 52, 221-259, 1986.

Hewitt, C. N., Lee, J. D., MacKenzie, A. R., Barkley, M. P., Carslaw, N., Carver, G. D., Chappell, N. A., Coe, H., Collier, C., Commane, R., Davies, F., Davison, B., DiCarlo, P., Di Marco, C. F., Dorsey, J. R., Edwards, P. M., Evans, M. J., Fowler, D., Furneaux, K. L., Gallagher, M., Guenther, A., Heard, D. E., Helfter, C., Hopkins, J., Ingham, T., Irwin, M., Jones, C., Karunaharan, A., Langford, B., Lewis, A. C., Lim, S. F., MacDonald, S. M., Mahajan, A. S., Malpass, S., McFiggans, G., Mills, G., Misztal, P., Moller, S., Monks, P. S., Nemitz, E., Nicolas-Perea, V., Oetjen, H., Oram, D. E., Palmer, P. I., Phillips, G. J., Pike, R., Plane, J. M. C., Pugh, T., Pyle, J. A., Reeves, C. E., Robinson, N. H., Stewart, D., Stone, D., Whalley, L. K., and Yin, X.: Overview: oxidant and particle photochemical processes above a south-east Asian tropical rainforest (the OP3 project): introduction, rationale, location characteristics and tools, Atmos. Chem. Phys., 10, 169-199, doi:10.5194/acp-10169-2010, 2010.

Holzinger, R., Lee, A., Paw, K. T., and Goldstein, U. A. H.: Observations of oxidation products above a forest imply biogenic emissions of very reactive compounds, Atmos. Chem. Phys., 5, 67-75, doi:10.5194/acp-5-67-2005, 2005.

Hussein, M. Y., Lajis, N. H., Kinson, A., and Teo, C. B.: Laboratory and field evaluation on the attractancy of Elaeidobius kamerunicus Faust to 4-allylanisole, Porim Bull., 18, 20-26, 1989. 
Hussein, M. Y., Lajis, N. H., and Ali, J. H.: Biological and chemical factors associated with the successful introduction of Elaeidobius kamerunicus Faust, the oil palm pollinator in Malaysia, Acta Hort. (ISHS) 288, 81-87, 1991.

Jayne, J. T., Leard, D. C., Zhang, X. F., Davidovits, P., Smith, K. A., Kolb, C. E., and Worsnop, D. R.: Development of an aerosol mass spectrometer for size and composition analysis of submicron particles, Aerosol Sci. Technol., 33, 49-70, 2000.

Jimenez, J. L., Jayne, J. T., Shi, Q., Kolb, C. E., Worsnop, D. R., Yourshaw, I., Seinfeld, J. H., Flagan, R. C., Zhang, X. F., Smith, K. A., Morris, J. W., and Davidovits, P.: Ambient aerosol sampling using the Aerodyne Aerosol Mass Spectrometer, J. Geophys. Res.-Atmos., 108, 8425 doi:10.1029/2001jd001213, 2003.

Karl, T. G., Spirig, C., Rinne, J., Stroud, C., Prevost, P., Greenberg, J., Fall, R., and Guenther, A.: Virtual disjunct eddy covariance measurements of organic compound fluxes from a subalpine forest using proton transfer reaction mass spectrometry, Atmos. Chem. Phys., 2, 279-291, doi:10.5194/acp-2-279-2002, 2002.

Kim, S., Karl, T., Helmig, D., Daly, R., Rasmussen, R., and Guenther, A.: Measurement of atmospheric sesquiterpenes by proton transfer reaction-mass spectrometry (PTR-MS), Atmos. Meas. Tech., 2, 99-112, doi:10.5194/amt-2-99-2009, 2009.

Knudsen, J. T., Tollsten, L., and Ervik, F.: Flower scent and pollination in selected neotropical palms, Plant Biol., 3, 642-653, 2001.

Langford, B., Davison, B., Nemitz, E., and Hewitt, C. N.: Mixing ratios and eddy covariance flux measurements of volatile organic compounds from an urban canopy (Manchester, UK), Atmos. Chem. Phys., 9, 1971-1987, doi:10.5194/acp-9-1971-2009, 2009.

Lee, A., Goldstein, A. H., Keywood, M. D., Gao, S., Varutbangkul, V., Bahreini, R., Ng, N. L., Flagan, R. C., and Seinfeld, J. H.: Gas-phase products and secondary aerosol yields from the ozonolysis of ten different terpenes, J. Geophys. Res.-Atmos., 111, D07302, doi:10.1029/2005jd006437, 2006a.

Lee, A., Goldstein, A. H., Kroll, J. H., Ng, N. L., Varutbangkul, V., Flagan, R. C., and Seinfeld, J. H.: Gas-phase products and secondary aerosol yields from the photooxidation of 16 different terpenes, J. Geophys. Res.-Atmos., 111, D17305, doi:10.1029/2006jd007050, 2006b.

Lindinger, W., Hansel, A., and Jordan, A.: On-line monitoring of volatile organic compounds at pptv levels by means of protontransfer-reaction mass spectrometry (PTR-MS) - Medical applications, food control and environmental research, Int. J. Mass Spectrom., 173, 191-241, 1998.

Mahbob, A.: The Pollinator E. Camerunicus is Nature's little helper, Global Oil \& Fats Business Magazine, 5, 58-59, 2008.

Misztal, P. K., Nemitz, E., Langford, B., Coyle, M., Ryder, J., DiMarco, C., Phillips, G., Oram, D., Owen, S., Heal, M. R., and Cape, J. N.: First direct ecosystem fluxes of VOCs from oil palms in SE Asia, in preparation, 2010.

Monson, R. K., Harley, P. C., Litvak, M. E., Wildermuth, M., Guenther, A. B., Zimmerman, P. R., and Fall, R.: Environmental and developmental controls over the seasonal pattern of isoprene emission from aspen leaves, Oecologia, 99, 260-270, 1994.

Nemitz, E., Loubet, B., Lehmann, B. E., Cellier, P., Neftel, A., Jones, S. K., Hensen, A., Ihly, B., Tarakanov, S. V., and Sutton, M. A.: Turbulence characteristics in grassland canopies and implications for tracer transport, Biogeosciences, 6, 1519-1537, doi:10.5194/bg-6-1519-2009, 2009.

Nemitz, E., Phillips, G. J., Di Marco, C. F., Siong, J., Farmer, D., Kimmel, J., Jimenez, J., and Fowler, D.: Concentrations and fluxes of submicron aerosol components above an oilpalm plantation in Sabah, Malaysia, in preparation, 2010.

Petron, G., Harley, P., Greenberg, J., and Guenther, A.: Seasonal temperature variations influence isoprene emission, Geophys. Res. Lett., 28, 1707-1710, 2001.

Rinne, H. J. I., Guenther, A. B., Warneke, C., de Gouw, J. A., and Luxembourg, S. L.: Disjunct eddy covariance technique for trace gas flux measurements, Geophys. Res. Lett., 28, 3139-3142, 2001.

Rinne, J., Taipale, R., Markkanen, T., Ruuskanen, T. M., Hellén, H., Kajos, M. K., Vesala, T., and Kulmala, M.: Hydrocarbon fluxes above a Scots pine forest canopy: measurements and modeling, Atmos. Chem. Phys., 7, 3361-3372, doi:10.5194/acp-73361-2007, 2007.

Rosenstiel, T. N., Potosnak, M. J., Griffin, K. L., Fall, R., and Monson, R. K.: Increased $\mathrm{CO}_{2}$ uncouples growth from isoprene emission in an agriforest ecosystem, Nature, 421, 256259, doi:10.1038/nature01312, 2003.

Sharkey, T. D., Singsaas, E. L., Lerdau, M. T., and Geron, C. D.: Weather effects on isoprene emission capacity and applications in emissions algorithms, Ecol. Appl., 9, 1132-1137, 1999.

Spirig, C., Neftel, A., Ammann, C., Dommen, J., Grabmer, W., Thielmann, A., Schaub, A., Beauchamp, J., Wisthaler, A., and Hansel, A.: Eddy covariance flux measurements of biogenic VOCs during ECHO 2003 using proton transfer reaction mass spectrometry, Atmos. Chem. Phys., 5, 465-481, doi:10.5194/acp-5-465-2005, 2005.

Steinbacher, M., Dommen, J., Ammann, C., Spirig, C., Neftel, A., and Prevot, A. S. H.: Performance characteristics of a protontransfer-reaction mass spectrometer (PTR-MS) derived from laboratory and field measurements, Int. J. Mass Spectrom., 239, 117-128, 2004.

Sutton, M. A., Burkhardt, J. K., Guerin, D., Nemitz, E., and Fowler, D.: Development of resistance models to describe measurements of bi-directional ammonia surface-atmosphere exchange, International Conference on Atmospheric Ammonia - Emissions, Deposition and Environmental Impacts, Culham, England, ISI:000072633600029, 473-480, 1995.

Syed, R. A.: Studies on oil palm pollination by insects, Bull. Ent. Res., 69, 1979.

Taipale, R., Ruuskanen, T. M., Rinne, J., Kajos, M. K., Hakola, H., Pohja, T., and Kulmala, M.: Technical Note: Quantitative long-term measurements of VOC concentrations by PTR-MS measurement, calibration, and volume mixing ratio calculation methods, Atmos. Chem. Phys., 8, 6681-6698, doi:10.5194/acp8-6681-2008, 2008.

Tandon, R., Manohara, T. N., Nijalingappa, B. H. M., and Shivanna, K. R.: Pollination and Pollen-pistil Interaction in Oil Palm, Elaeis guineensis, Ann. Bot., 87, 831-838, doi:10.1006/anbo.2001.1421, 2001.

Terry, I., Moore, C. J., Walter, G. H., Forster, P. I., Roemer, R. B., Donaldson, J. D., and Machin, P. J.: Association of cone thermogenesis and volatiles with pollinator specificity in Macrozamia cycads, Plant Syst. Evol., 243, 233-247, doi:10.1007/s00606003-0087-x, 2004.

Test Plan for Estragole: http://www.epa.gov/HPV/pubs/summaries/ 
estragole/c14022tp.pdf, (last access: 21 April 2009), 2002.

US Environmental Protection Agency Estimation Program Interface (EPI): Suite v3.2: http://www.epa.gov/opptintr/exposure/pubs/ episuite.htm, (last access: 21 September 2009), 2007.

Wang, Y. F., Owen, S. M., Li, Q. J., and Penuelas, J.: Monoterpene emissions from rubber trees (Hevea brasiliensis) in a changing landscape and climate: chemical speciation and environmental control, Glob. Change Biol., 13, 2270-2282, 2007.
White, M. L., Russo, R. S., Zhou, Y., Ambrose, J. L., Haase, K., Frinak, E. K., Varner, R. K., Wingenter, O. W., Mao, H., Talbot, R., and Sive, B. C.: Are biogenic emissions a significant source of summertime atmospheric toluene in the rural Northeastern United States?, Atmos. Chem. Phys., 9, 81-92, doi:10.5194/acp9-81-2009, 2009. 